and in 1903 was issued the full Report of the Geological Survey (dated 1902) on the "Topography and Geology of the Eastern Desert of Egypt," with maps, plates, and sections. His services were called for on questions of irrigation, in the survey of the peninsula of Sinai, and in an exploration for coal in Abyssinia. In 1904 he conducted an expedition in the Soudan with the object of finding water, and in the following year he becane Geological Surveyor to the Soudan Government.

$\mathrm{He}$ died of enteric fever at El Koweit, Suakim, on the 30th of January, aged 39.

\title{
WILLIAM CUNNINGTON, F.G.S.
}

Borx 1813.

Died Ferrtary, 1906.

THE death, in his ninety-third year, of William Cunnington removes one of the more distinguished local geologists and antiquaries whose observations and collections have done much to advance science. During the middle portion of last century the name of William Cunnington, of Devizes, became familiar to geologists. His extensive collection of the Cretaceous fossils of Wiltshire furnished materials which aided Davidson in his Monograph on Cretaceous Brachiopoda, Wright in his Cretaceous Echinodermata, and Daniel Sharpe in his Cretaceous Cephalopoda; and in the last-mentioned work Ammonites Cunningtoni, from the Lower Chalk near Devizes, was named in his honour. For many years Cunnington was one of the honorary secretaries of the Palæontographical Society. He was elected a Fellow of the Geological Society in 1854. He obtained a fine series of sponges from the Upper Greensand of Warminster, and many of these are described or mentioned in Dr. G. J. Hinde's "Catalogue of the Fossil Sponges in the Geological Department of the British Museum."

He was a grandson of William Cunnington, F.S.A., of Heytesbury in Wiltshire, who was interested in geological pursuits, probably through acquaintance with William Smith, and celebrated for his antiquarian researches in the county, in which he was associated with Sir Richard Colt Hoare. While a lad be began to collect fossils from the chalk-pits of Upavon, and subsequently, when he had settled at Devizes as a wine merchant, he assiduously studied the local geology-especially the strata from the Great Oolite Series to the Portland Beds, the Lower Greensand, the Gault, Upper Greensand, and Chalk; and he ultimately amassed a collection of more than 20,000 fossils. He was one of the founders of the Devizes Museum, and was honorary curator from the time of its opening in $18 \tilde{3} 3$.

One of his earliest papers was "On the Fossil Cephalopoda from the Oxford Clay constituting the genus Belemnoteuthis (Pearce)," London Geol. Journ., No. 3, 1847, p. 1. Most of his contributions to reological literature were, however, published in the Magazine of the Wiltshire Archæological and Natural History Society; they included 
papers on "The Mammalian Drift of Wiltshire" (1857), "The Bradford Clay" (1859), "Geology of Wiltshire" (1869), and "Geology of the neighbourhood of Westbury Station" (1872). To the Geological Society he communicated in 1850 a paper "On a section of the Lower Greensand at Seend, near Devizes" (Q.J.G.S., vi, 453), and a second paper in 1898 "On some Palæolithic Implements from the Plateau-Gravels, and their evidence concerning 'Eolithic' Man" (Q.J.G.S., liv, 291). He also published in Natural Science, vol. xi (1897), p. 327, a paper on "The Authenticity of Plateau-Man," in which he doubted the human origin of the 'Eolithic' chipping.

Mr. Cunnington retired from Devizes many years ago and settled in London.

His collections of fossils have been placed in the British Museum (Natural History), in the Museum of Practical Geology, and in the Devizes Museum.

For some of the above particulars we are indebted to "The History of the Collections contained in the Natural History Departments of the British Museum," vol. i (1904), pp. 281-2.

Under the title of "Fossils used as Ornaments" there is a reprint" in the Grologidal Magazine, 1893, p. 248, of an interesting article "On a Crapaudine Locket found in St. John's Churchyard, Devizes," by William Cunnington, F.G.S., of which figures are given. The interest to geologists lies in the fact that the sides of the locket are formed of two detached circular palatal teeth of Lepidotus maximus. Wagner = Spherodus gigas, Ag., from the Kimmeridge Clay of Shotover.

\section{MISCEIIAIFOUS.}

Chair of Geology in the Royal College of Science, South Kensington. - The President of the Board of Education has appointed Professor W. W. Watts, M.A., F.R.S., of Birmingham University, to the Chair of Geology at the Royal College of Science, South Kensington, vacant by the retirement of Prof. Judd, C.B., F.R.S.

In view of the changes in organisation that may be found desirable in the Royal College of Science and the Royal School of Mines after the consideration of the report of the Department Committee on the college, it has been thought best to make this appointment a temporary one.

Professor Watts was a Fellow of Sidney Sussex College, Cambridge, from 1888 to 1894, and a member of the Geological Survey from 1891 to 1897. He has acted successively as Deputy Professor of Geology at Leeds, Birmingham, and Oxford. At the present time he is Assistant Professor of Geology and Professor of Geography at the Birmingham University, and is Secretary of the Geological Society.-Standard, January 23rd, 1906.

1 See the Wilts Archæological Magazine, 1870, No. $x x x y$, p. 249. 